\title{
Pengembangan SSP Model SLH untuk Penumbuhkembangan Keterampilan Proses Sains dan Karakter Peduli Lingkungan Siswa
}

\author{
Riya Irianti $^{1} *$, Heru Nurcahyo ${ }^{2}$ \\ ${ }^{12}$ Program Studi Pendidikan Sains Program Pascasarjana, Universitas Negeri Yogyakarta. Jalan \\ Colombo No. 1, Karangmalang, Yogyakarta 55281, Indonesia \\ * Korespondensi Penulis. E-mail: riyairianti5011@gmail.com
}

\begin{abstract}
Abstrak
Penelitian ini bertujuan untuk mengetahui kevalidan, kepraktisan, dan keefektifan perangkat pembelajaran biologi berbasis Model Susan Loucks Horsley setting outdoor activities untuk penumbuhkembangan keterampilan proses sains dan karakter peduli lingkungan. Penelitian ini menggunakan metode research and development (R\&D) yang dikembangkan oleh Borg \& Gall. Uji coba lapangan menggunakan dua kelas yang dipilih menggunakan teknik simple random sampling. Teknik analisis data yang digunakan adalah konversi skor ke nilai. Hasil penelitian ini menunjukkan bahwa perangkat pembelajaran berbasis model Susan Loucks Horsley setting outdoor activities ini memenuhi kriteria valid, praktis, dan efektif dalam menumbuhkembangkan keterampilan proses sains dan karakter peduli lingkungan peserta didik. Kevalidan produk terlihat dari hasil uji validasi yang menyatakan bahwa produk mencapai kriteria sangat valid. Kepraktisan produk terlihat dari hasil pengisian lembar respon peserta didik menunjukkan kriteria sangat praktis untuk handout dan proses pembelajaran serta praktis untuk LKPD; dan lembar observasi keterlaksanaan pembelajaran menunjukkan bahwa persentase keterlaksanaan pembelajaran yang berada pada kisaran 91,7\% sampai $100 \%$. Keefektifan didukung dengan hasil uji beda antara kelas kontrol dan eksperimen yang menunjukkan adanya perbedaan rata-rata nilai hasil belajar, dan skor angket karakter kepedulian lingkungan yang signifikan antara dua kelas tersebut dengan taraf signifikansi 0,05.
\end{abstract}

Kata Kunci: pengembangan, perangkat pembelajaran, keterampilan proses sains, karakter peduli lingkungan

\section{Developing of SLH's Model of SSP to Increase Student's Science Process Skills and Environmental Care}

\begin{abstract}
This study aims to investigate the validity, practicality, and effectiveness of biology tool based learning model of Susan Loucks Horsley setting outdoor activities to increase science process skills and environmental care. This study used research and development $(R \& D)$ of Borg \& Gall. Try out was conducted by using two classes which were selected using simple random sampling technique. The data analysis technique was the score conversion into grades. The results of this research shows that the sets based-learning of Susan Loucks Horsley's model with setting outdoor activities meets the criteria for validity, practicality, and effectiveness to increase science process skills and environmental care of the students. Validity of the products shown on the validation test results stating that the product reaches a very valid criteria. Practicality of the product seen from the results of the student's response sheets which shows a very practical criteria for handouts and learning processes as well as practical for LKPD; and observation sheet feasibility study shows that apercentage feasibility study which is in the range of $91,7 \%$ until 100\%. This effectiveness is also supported by t-test indicating the difference of grades study results, science process skills and environmental care of the score mean between the control and experimental class is significant with significance level of 0.05.
\end{abstract}

Keywords: development, the sets of learning, science process skills and environmental care

How to Cite: Irianti, R., \& Nurcahyo, H. (2016). Pengembangan SSP model SLH untuk penumbuhkembangan keterampilan proses sains dan karakter peduli lingkungan siswa. Jurnal Inovasi Pendidikan IPA, 2(1), 122-133. doi:http://dx.doi.org/10.21831/jipi.v2i1.11989

Permalink/DOI: http://dx.doi.org/10.21831/jipi.v2i1.11989 


\section{Jurnal Inovasi Pendidikan IPA, 2 (1), 2016 - 123}

Riya Irianti, Heru Nurcahyo

\section{PENDAHULUAN}

Kementerian Pendidikan dan Kebudayaan (Kemendikbud) saat ini tengah memberlakukan implementasi kurikulum baru pada dunia pendidikan yaitu Kurikulum 2013. Implementasi Kurikulum 2013 merupakan pengembangan dari Kurikulum Berbasis Kompetensi (KBK) yang telah dirintis pada tahun 2004 dan Kurikulum Tingkat Satuan Pendidikan (KTSP) pada tahun 2006. Penerapan Kurikulum 2013 bertujuan memfasilitasi sekolah sebagai lembaga pendidikan formal agar dapat meningkatkan peranannya dalam menumbuhkembangkan kompetensi sikap, pengetahuan, dan keterampilan peserta didik secara terpadu.

Keterampilan Proses Sains (KPS) dan pendidikan karakter dalam Pendidikan Sains perlu di integrasikan dalam sistem pendidikan. Pendidikan sains yang diterapkan dengan KPS akan membuat peserta didik belajar proses, produk, dan nilai ilmu pengetahuan sekaligus. Bundu (2006, pp. 6-8) menyatakan bahwa dalam proses pembelajaran, pengembangan konsep tidak dapat dipisahkan dari proses, produk, dan nilai. Ada dua macam KPS yang harus dipelajari oleh peserta didik. Menurut Rezba et al. (2006, pp.1\&117) keterampilan proses terdiri atas keterampilan proses dasar dan keterampilan proses terintegrasi.

Semiawan, Tangyong, Belen, Matahelemual, \& Suseloardjo (1992, p.18) menjelaskan bah-wa dengan mengembangkan KPS akan mampu menumbuhkembangkan fakta dan konsep serta sikap dan nilai yang dituntut. Penumbuhkem-bangan fakta, konsep, sikap dan nilai akan mewadahi pembentukan karakter yang sekaligus menjadi tujuan pendidikan nasional. Berdasar-kan lampiran Standar Isi Permendikbud Nomor 64 tahun 2013 dijelaskan bahwa terdapat empat kompetensi yang harus dicapai peserta didik yaitu sikap spiritual, sikap sosial, pengetahuan dan keterampilan. Sikap sosial yang harus dica-pai terdapat perilaku ilmiah berupa perilaku peduli lingkungan yang menjadi salah satu kompetensi dasar peserta didik di SMA.

Berdasarkan hasil observasi di SMAN 6 Yogyakarta teridentifikasikan beberapa permasalahan. Permasalahan tersebut diantaranya yaitu: (1) sebagian besar peserta didik SMAN 6 Yogyakarta belum mempunyai KPS untuk kegiatan daur ulang pengomposan, (2) hasil penguasaan materi peserta didik SMAN 6 Yogyakarta pada materi perubahan/pencemaran ling- kungan belum optimal, (3) belum ada perangkat pembelajaran biologi khusus untuk pemanfaatan Pasar Terban sebagai sumber belajar, (4) belum ada perangkat pembelajaran biologi khusus untuk keterampilan daur ulang limbah dengan pengomposan,(5) belum mempunyai perangkat pembelajaran biologi dengan model SLH setting outdoor activities untuk penumbuhkembangan KPS dan KPL.

Penumbuhkembangan KPS dan KPL dapat dioptimalkan dengan pembelajaran melalui suatu perangkat pembelajaran biologi dengan model pembelajaran yang tepat, secara jelas dan sistematis dapat memanifestasikan nilai-nilai/ karakter ke dalam kurikulum dan tentu saja konsep serta skill dari pembelajaran sains itu sendiri. Model pembelajaran yang dipilih secara efektif dapat digunakan dalam pencapaian penumbuhkembangan KPS dan KPL.

Salah satu model pendidikan sains yang memberi petunjuk secara spesifik proses belajarmengajarnya adalah model yang dikembangkan oleh Susan Loucks-Horsley dan kawan-kawan (McCormack, 1992, p.27). Prosedur tahapan pembelajaran model SLH dengan setting outdoor activities ini sejalan dengan kegiatan pembelajaran yang dirancang dalam Kurikulum 2013 yaitu: mengamati, menanya, mengumpulkan informasi, mengasosiasikan, dan mengkomunikasikan. Model ini akan mampu membantu peserta didik dalam mencapai standar kompetensi lulusan dari semua domain dalam Kurikulum 2013 yaitu domain sikap, keterampilan dan pengetahuan. Model pembelajaran SLH dalam penerapannya di sekolah dipandang mampu meningkatkan mutu pembelajaran berbasis konstruktivistik dengan aktivitas-aktivitas di dalamnya yang sesuai dengan tujuan dalam lima ranah Taksonomi Pendidikan Sains, dan mampu merefleksikan hubungan antara sains dan teknologi.

Pada penelitian ini dari aspek sains model ini akan mengantarkan peserta didik memahami permasalahan lingkungan melalui kegiatan berbasis metode ilmiah (inkuiri). Dari aspek teknologi mengantarkan peserta didik memecahkan dan mencari solusi terhadap permasalahan lingkungan melalui suatu teknik/metode daur ulang yaitu dengan kegiatan pengomposan. Pembelajaran dengan model SLH melalui kegiatan pengomposan akan sangat berpotensi menumbuhkembangkan KPL peserta didik dengan menggunakan sumber belajar lagsung dari lingkungan nyata. 
Lingkungan pembelajaran yang nyata dapat diperoleh melalui pembelajaran di luar kelas (outdoor activities). Peserta didik dapat diajak untuk melihat secara langsung permasalahan lingkungan di sekitar sekolah. Outdoor activities dikembangkan dalam proses pembelajaran dengan tujuan agar pembelajaran berjalan lebih produktif dan bermakna (Supahar, 2010, p.386). Berdasarkan penelitian ini pembelajaran yang membawa peserta didik lebih dekat dengan objek pembelajaran supaya pembelajaran lebih bermakna, misalnya: lingkungan sekitar sekolah.

Keterampilan proses sains yang dapat ditumbuhkembangkan pada penelitian ini adalah observasi, klasifikasi, membuat hipotesis, menentukan variabel, melakukan eksperimen dan mengkomunikasikan serta karakter yang dapat ditumbuhkembangkan adalah karakter peduli lingkungan. Fokus pembahasan diarahkan pada penumbuhkembangan KPS dan KPL dilihat dari aktivitas peserta didik dalam proses pembelajaran dengan perangkat pembelajaran biologi berbasis model SLH dengan setting outdoor activities.

Menurut Depdiknas (2008, pp.47-49), penelitian pengembangan adalah rangkaian proses dalam rangka mengembangkan suatu produk baru atau menyempurnakan produk yang telah ada agar dapat dipertanggungjawabkan. Pada penelitian ini, penelitian yang dilakukan bertujuan untuk mengembangkan perangkat pembelajaran yang valid, praktis, dan efektif sesuai dengan kondisi dan realita karena kualitas produk pengembangan dipertimbangkan dari tiga aspek, yaitu validitas (validity), kepraktisan (practically), dan keefektifan (effectivity) (Nieveen, 1999, p.127)

Trianto (2009, p.201) mengemukakan "perangkat yang dipergunakan dalam proses pembelajaran disebut dengan perangkat pembelajaran". Perangkat pembelajaran yang dikembangkan dapat dijadikan sebagai salah satu sumber inspirasi untuk solusi dari permasalahan yang sedang dihadapi. Perangkat pembelajaran yang diperlukan dalam mengelola proses belajar mengajar dalam penelitian ini berupa: silabus, Rencana Pelaksanaan Pembelajaran (RPP), materi ajar (Handout), Lembar Kerja Peserta Didik (LKPD), instrumen penilaian berbasis model SLH soutdoor activities.

Model pembelajaran SLH terintegrasi dengan materi "Pengaruh Aktivitas Manusia terhadap Perubahan dan Pencemaran Lingkungan" sehingga berpontesi dapat menumbuhkembangkan KPS dan KPL peserta didik kelas X
SMAN 6 Yogyakarta dalam proses pembelajaran.

\section{METODE}

Jenis penelitian ini merupakan penelitian dan pengembangan (research and development) yang berarti penelitian ini berorientasi pada produk. Produk yang dikembangkan dalam penelitian ini berupa perangkat pembelajaran dalam bentuk silabus, Rencana Pelaksanaan Pembelajaran (RPP), bahan ajar berupa handout, Lembar Kegiatan Peserta Didik (LKPD), dan instrumen penilaian. Pada penelitian ini perangkat pembelajaran yang dikembangkan berbasis model Susan Loucks Horsley (SLH) setting outdoor activities yang hasilnya diharapkan dapat menumbuhkembangkan Keterampilan Proses Sains (KPS) dan Karakter Peduli Lingkungan (KPL) peserta didik kelas X SMAN 6 Yogyakarta.

Penelitian ini dilaksanakan di SMAN 6 Yogyakarta, dari bulan Maret hingga Mei 2014. Subjek uji coba perangkat pembelajaran biologi berbasis model SLH setting outdoor activities adalah peserta didik kelas XI dan X SMAN 6 Yogyakarta semester 2 tahun ajaran 2013/2014. Subyek uji coba yaitu terdiri atas 29 orang peserta didik kelas XI IPA sebagai subyek uji coba validasi empiris THB, Subjek uji coba terbatas berjumlah 6 orang peserta didik kelas X yang dipilih dari dua peserta didik kemampuan kognitif rentang atas, dua peserta didik kemampuan kognitif rentang tengah, dan dua peserta didik kemampuan kognitif rentang bawah berdasarkan nilai UTS.

Subjek uji coba lapangan adalah kelas $\mathrm{X}$ sebanyak dua kelas, masing-masing kelasnya digunakan 24 peserta didik untuk kelas kontrol dan 30 peserta didik untuk kelas eksperimen. Para peserta didik dari kedua kelas yang dipilih sebagai subjek uji merupakan peserta didik yang dipilih secara acak (random) tetapi pada kemampuan kognitif kelas yang sama mengacu pada nilai UTS rata-rata kelas.

Pelaksanaan penelitian mengikuti prosedur sebagai berikut: (1) tahap studi pendahuluan, (2) tahap perencanaan, (3) tahap penyusunan draft, (4) tahap validasi produk awal, (5) tahap uji coba(6) desiminasi. Teknik pengambilan data menggunakan metode tes, observasi dan angket. Untuk memperoleh data menggunakan instrumen (1) lembar validasi perangkat pembelajaran; (2) lembar soal THB yaitu 30 soal pilihan ganda untuk pretest-posttest; (3) lembar observasi KPS peserta didik; (4) lembar angket yang 
terdiri atas lembar angket KPL peserta didik dan lembar angket respon peserta didik terhadap perangkat dan proses pembelajaran; (5) lembar pengamatan keterlaksanaan pembelajaran.

Penelitian ini menggunakan desain Pretest-Postest Control Group Design dengan rancangan pada Tabel 1.

Tabel 1. Pretest-Postest Control Group Design

\begin{tabular}{cccc}
\hline Group & Pretest & Perlakuan & Postest \\
\hline $\mathrm{KK}$ & $O_{1}$ & - & $O_{2}$ \\
$\mathrm{KE}$ & $O_{1}$ & $\mathrm{X}$ & $O_{2}$ \\
\hline
\end{tabular}

Keterangan

KK: Kelas Kontrol

KE: Kelas Eksperimen

$O_{1}$ :Tes kemampuan awal (pretest)

$\mathrm{O}_{2}$ : Tes hasil belajar (posttest)

$\mathrm{X}$ : Pembelajaran biologi menggunakan perangkat pembelajaran biologi berbasis model SLH setting outdoor activities

Teknik pengumpulan data pada penelitian ini yaitu dengan observasi, angket dan tes. Instrumen lembar validasi perangkat pembelajaran digunakan untuk memperoleh data tentang penilaian dari para validator (ahli materi, ahli pembelajaran, praktisi dan teman sejawat) terhadap perangkat pembelajaran yang digunakan dalam pengembangan yang disusun dengan menggunakan skala likert. Data hasil penilaian ini dijadikan dasar untuk perbaikan masingmasing perangkat pembelajaran sebelum diujicobakan. Instrumen Tes Hasil Belajar (THB) digunakan untuk mengetahui tingkat pemahaman peserta didik terhadap materi pembelajaran setelah diterapkannya model belajar dan perangkat pembelajaran yang dikembangkan juga untuk mengukur ketercapaian KPS peserta didik. Tes diberikan dua kali yaitu sebelum proses pembelajaran (pretest) dan setelah seluruh rangkaian pembelajaran selesai (posttest). Instrumen lembar observasi KPS digunakan untuk mengamati aktivitas penyelidikan dan pembelajaran yang dilakukan peserta didik dalam rangka pengembangan KPS (melihat tingkat ketercapaian penumbuhkembangan KPS pada peserta didik).

Instrumen lembar angket terbagi atas dua jenis yaitu: (1) angket untuk mengukur tingkat KPL peserta didik; (2) Angket untuk mendapatkan respon dari peserta didik tentang kegiatan pembelajaran setelah penerapan model belajar yang dikembangkan oleh peneliti beserta perangkat pembelajarannya. Pada Angket KPL pengukuran data didasarkan pada skor yang diperoleh peserta didik dari hasil pengisian angket tentang KPL yang mereka miliki. Angket respon peserta didik diberikan untuk mendapatkan informasi tentang respon peserta didik terhadap perangkat pembelajaran (handout dan LKPD) serta terhadap proses pembelajaran. Angket ini diberikan dengan tujuan untuk melihat tingkat kepraktisan perangkat pembelajaran.

Pengolahan data dalam penelitian ini dilakukan dengan menggunakan analisis deskriptif kuantitatif. Teknik analisis data untuk kelayakan perangkat pembelajaran yang dikembangkan sebagai data untuk menilai tingkat kevalidan produk dilakukan dengan mentabulasi semua data yang diperoleh dari para validator untuk setiap komponen, sub komponen dari butir penilaian yang tersedia dalam istrumen penilaian. Menghitung skor total rata-rata dari setiap komponen dengan menggunakan rumus mean kemudian data dan perangkat pembelajaran yang mula-mula berupa skor, diubah menjadi data kualitatif (data interval) dengan skala empat. Acuan pengubahan skor menjadi nilai skala empat tersebut menurut Direktorat Pembinaan SMA (2010b, p.60).

Teknik analisis data kepraktisan yaitu dengan menggunakan instrumen angket respon peserta didik dan dengan lembar observasi keterlaksanaan RPP. Analisis data respon peserta didik dilakukan dengan menghitung skor rata-rata respon peserta didik, kemudian mengkonversi ke dalam data kualitatif. Analisis keterlaksanaan RPP dari data observasi yaitu dengan menghitung persentase ketercapaian aktivitas pada setiap pertemuan. Penilaian terhadap keterlaksanaan fase-fase sintaks pembelajaran dengan menggunakan perangkat pembelajaran oleh satu pengamat yang sudah dilatih sehingga dapat mengoperasikan lembar observasi secara benar. Kriteria setiap fase dalam sintaks yang dimaksud adalah terlaksana dan tidak terlaksana. Berdasarkan hasil analisis data observasi keterlaksanaan pembelajaran, perangkat pembelajaran yang dikembangkan dikatakan praktis jika persentasi keterlaksanaan pembelajaran mencapai $80 \%$.

Teknik analisis data keefektifan terdiri atas: (1) teknik analisis THB dengan menghitung hasil tes untuk menentukan tingkat ketuntasan belajar peserta didik sesudah menggunakan perangkat pembelajaran yang dikembangkan. Data dari hasil peserta didik dalam mengerjakan THB akan dianalisis untuk melihat keefektifan perangkat pembelajaran untuk penumbuhkembangan KPS yaitu dengan menghitung 
persentase ketuntasan peserta didik. Peserta didik dinyatakan tuntas ketika perolehan skor telah mencapai KKM yaitu 75 .

Ketercapaian penumbuhkembangan KPS melalui peningkatan nilai THB juga melalui skor rata-rata lembar observasi KPS. Analisis data observasi KPS dilakukan dengan menghitung skor rata-rata ketercapaian KPS peserta didik, kemudian mengkonversi ke dalam data kualitatif. Karakter peduli lingkungan peserta didik dilihat dari skor peningkatan karakter dari rata-rata skor angket.

\section{HASIL DAN PEMBAHASAN}

Perangkat pembelajaran yang telah diperoleh dari realisasi perencanaan masuk dalam proses validasi untuk melihat tingkat kevalidan produk berdasarkan penilaian para ahli, praktisi dan teman sejawat. Perangkat ini telah divalidasi oleh sepuluh orang validator dengan rincian ahli materi (1 orang), ahli pembelajaran (1 orang), guru Biologi SMA (6 orang), dan teman sejawat (2 orang). Skor validasi dari seluruh validator dijumlahkan kemudian dirata-rata. Perangkat pembelajaran selain diberikan untuk penilaian, validator juga memberikan masukan sebagai evaluasi dan bahan perbaikan untuk produk yang dikembangkan. Hasil penilaian dari validator terhadap draf I terdapat pada Tabel 2 dan 3 .

Berdasarkan data pada Tabel 2 dan 3 diketahui perolehan skor rata-rata masing-masing produk. Hasil validasi terhadap perangkat pembelajaran oleh semua validator menunjukkan bahwa silabus mendapat skor rata-rata 33,1; RPP dengan skor 60,3; handout dengan skor 98; LKPD dengan skor 43,4; THB dengan skor 37,3 dan instrumen penilaian mendapat skor 22 untuk lembar observasi KPS, 22,3 untuk lembar angket KPL dan lembar angket respon peserta didik, dan 23,1 untuk lembar keterlaksanaan RPP. Setelah dilakukan perhitungan konversi kriteria maka pada seluruh komponen perangkat yang terdiri atas silabus, RPP, handout, LKPD, THB dan instrumen penilaian dengan kriteria sangat valid.

Penilaian juga dilakukan pada aspek-aspek yang terdapat pada perangkat pembelajaran biologi berbasis model SLH setting outdoor activities yang dikembangkan. Produk ini penilaiannya juga pada aspek-aspeknyayaitu pada produk RPP, handout, LKPD, THB, dan instrumen penilaian. Berikut penilaian aspek-aspek perangkat tersebut:

Tabel 2. Skor Hasil Validasi Perangkat Pembelajaran

\begin{tabular}{cccccc}
\hline \multirow{2}{*}{ Validator } & \multicolumn{5}{c}{ Skor Produk yang Divalidasi } \\
\cline { 2 - 6 } & Silabus & R RPP & Hand out & LKPD & THB \\
\hline 1 & 30 & 55 & 91 & 37 & 40 \\
2 & 34 & 63 & 100 & 42 & 34 \\
3 & 36 & 68 & 108 & 44 & 40 \\
4 & 36 & 62 & 102 & 41 & 38 \\
5 & 27 & 52 & 88 & 33 & 30 \\
6 & 34 & 57 & 93 & 40 & 39 \\
7 & 34 & 64 & 106 & 41 & 38 \\
8 & 30 & 52 & 82 & 33 & 39 \\
9 & 35 & 65 & 106 & 42 & 37 \\
10 & 35 & 65 & 104 & 81 & 38 \\
Skor Total & 331 & 603 & 980 & 434 & 373 \\
Rata-rata & 33.1 & 90.3 & 43.4 & 37.3 \\
Kriteria & S Sangat Valid & S Sangat Valid & Sangat Valid & Sangat Valid & Sangat Valid \\
\hline
\end{tabular}


Jurnal Inovasi Pendidikan IPA, 2 (1), 2016 - 127

Riya Irianti, Heru Nurcahyo

Tabel 3. Skor Hasil Validasi Instrumen Penilaian

\begin{tabular}{ccccc}
\hline \multirow{2}{*}{ Validator } & $\begin{array}{c}\text { Lembar Observasi } \\
\text { KPS }\end{array}$ & $\begin{array}{c}\text { Lembar Angket } \\
\text { KPL }\end{array}$ & $\begin{array}{c}\text { Lembar Keterlaksaan } \\
\text { RPP }\end{array}$ & $\begin{array}{c}\text { Angket Respon } \\
\text { Peserta Didik }\end{array}$ \\
\hline 1 & 21 & 22 & 24 & 24 \\
2 & 23 & 21 & 22 & 24 \\
3 & 24 & 24 & 24 & 24 \\
4 & 23 & 23 & 23 & 23 \\
5 & 18 & 18 & - & 18 \\
6 & 19 & 24 & 22 & 20 \\
7 & 23 & 22 & 23 & 22 \\
8 & 24 & 24 & 24 & 24 \\
9 & 22 & 22 & 23 & 22 \\
10 & 23 & 223 & 23 & 223 \\
Skor total & 220 & 22.3 & 208 & 22.3 \\
Rata-Rata & 22 & Sangat valid & Sangat valid & Sangat valid \\
Kriteria & Sangat valid & & & \\
\hline
\end{tabular}

Tabel 4. Hasil Analisis Validasi RPP pada Setiap Aspek Penilaian

\begin{tabular}{cccc}
\hline No & Aspek yang dinilai & Skor Rata-rata & Kriteria \\
\hline 1 & Identitas mata pelajaran & 7.5 & Sangat valid \\
2 & Rumusan tujuan/indikator & 3.5 & Sangat valid \\
3 & Model pembelajaran & 25 & Sangat valid \\
4 & Kegiatan pembelajaran & 7.2 & Sangat valid \\
5 & Pemilihan media/ sumber belajar & 6.9 & Sangat valid \\
6 & Penilaian hasil belajar & 10.2 & Sangat valid \\
\hline
\end{tabular}

Tabel 5. Hasil Analisis Validasi Handout Pada Setiap Aspek Penilaian

\begin{tabular}{|c|c|c|c|}
\hline No & Aspek yang dinilai & Skor Rata-rata & Kriteria \\
\hline 1 & Kelayakan Isi & 43,7 & Sangat valid \\
\hline 2 & Kebahasaan & 54,3 & Sangat Valid \\
\hline
\end{tabular}

Tabel 6. Hasil Validasi LKPD pada Setiap Aspek Penilaian

\begin{tabular}{llll}
\hline No & Aspek yang Dinilai & Skor Rata-Rata & Kriteria \\
\hline 1 & Kesesuaian isi dan materi & 18,1 & Sangat Valid \\
2 & Kesesuaian dengan syarat konstruksi & 10,6 & Sangat Valid \\
3 & Kesesuaian dengan syarat teknis & 10,8 & Sangat Valid \\
\hline
\end{tabular}

Tabel 7. Hasil Analisis Validasi THB pada Setiap Aspek Penilaian

\begin{tabular}{llll}
\hline No & Aspek yang dinilai & Skor Rata-rata & Kriteria \\
\hline 1 & Kesesuaian Teknik Penilaian dengan tujuan pembelajaran & 11.2 & Sangat Valid \\
2 & Kelengkapan soal & 22.3 & Sangat Valid \\
3 & Kebahasaan & 3.8 & Sangat Valid \\
\hline
\end{tabular}

Tabel 8. Hasil Analisis Validasi Instrumen Penilaian pada Setiap Aspek Penilaian

\begin{tabular}{cccccc}
\hline \multirow{5}{*}{ No } & \multicolumn{5}{c}{ Skor Rata-Rata } \\
\cline { 2 - 6 } & $\begin{array}{c}\text { Lembar } \\
\text { Observasi KPS }\end{array}$ & $\begin{array}{c}\text { Lembar } \\
\text { Angket KPL }\end{array}$ & $\begin{array}{c}\text { Lembar } \\
\text { Keterlaksanaan RPP }\end{array}$ & $\begin{array}{c}\text { Lembar Angket } \\
\text { Respon Peserta Didik }\end{array}$ & Kriteria \\
\hline 1 & 10.9 & 10.9 & 11.4 & 11 & Sangat Valid \\
2 & 11.1 & 11.4 & 11.67 & 11.3 & Sangat Valid \\
\hline
\end{tabular}

Berdasarkan analisis hasil penilaian pada produk RPP, Handout, LKPD, THB dan instrumen penilaian dari setiap aspek penilaian kemudian dengan perhitungan konversi kriteria yang menunjukkan bahwa aspek yang dinilai dari instrumen penilaian secara keseluruhan telah memenuhi kriteria sangat valid. 
Selain memberikan penilaian terhadap produk validator juga memberikan masukan sebagai bahan perbaikan, yaitu pada silabus kegiatan belajar lebih dijelaskan sehingga aktivitas belajar bisa lebih dimunculkan.

Pada RPP, masukan yang didapat adalah aktivitas yang dilakukan untuk menumbuhkembangkan KPS dan KPL, indikator, tujuan pembelajaran, materi pembelajaran serta alokasi waktu agar lebih dirinci.

Pada handout dilengkapi dengan keterangan urutan gambar serta keterangan sumber. Evaluasi untuk LKPD dilengkapi dengan nomor urut LKPD dan nomor urut tabel serta langkah kerja atau aktivitas perlu lebih di arahkan sehingga nantinya akan berujung pada kesimpulan yang diharapkan, sedangkan untuk THB lebih pada redaksi kalimat pertanyaan dan tata tulis pada option jawaban.

Kepraktisan perangkat pembelajaran diketahui dari analisis hasil respon peserta didik serta analisis dari hasil observasi keterlaksanaan pembelajaran pada saat uji coba terbatas dan uji coba lapangan. Analisis data kepraktisan untuk masing-masing perangkat pembelajaran berdasarkan respon peserta didik dapat dilihat pada Tabel 9.

Berdasarkan hasil respon peserta didik pada uji coba terbatas dan uji coba lapangan disimpulkan bahwa perangkat pembelajaran yang terdiri atas handout dan proses pembelajaran masuk ke dalam kriteria sangat praktis dan LKPD masuk dalam kriteria praktis sehingga perangkat sudah termasuk dalam kriteria sangat baik untuk handout dan proses pembelajaran serta baik untuk LKPD. Hasil ini merepresentasikan bahwa produk yang dikembangkan mudah digunakan bagi peserta didik dan proses yang dilaksanakan efektif serta efisien. Analisis data kepraktisan juga diperoleh dari data observasi keterlaksanaan pembelajaran pada setiap pertemuan di uji coba terbatas dan uji coba lapangan. Analisis data tersebut disajikan pada Tabel 11 dan Tabel 12.

Berdasarkan hasil analisis pada Tabel 11 dan 12 diketahui bahwa pada setiap pertemuan, persentase keterlaksanaan pembelajaran telah mencapai di atas $80 \%$. Dari data tersebut maka dapat di analisis bahwa perangkat pembelajaran telah mencapai kriteria praktis ditinjau dari keterlaksanaan pembelajaran.

Analisis keefektifan bagi penumbuhkembangan KPS diperoleh dari data hasil THB yang dilaksanakan pada awal pertemuan pertama dan akhir pertemuan keempat. Tes Hasil Belajar (THB) digunakan untuk mengukur ketercapaian penumbuhkembangan KPS dan pemahaman konsep peserta didik. Data hasil tes hasil belajar dapat dilihat pada Tabel 13, 14 dan 15.

Tabel 9. Hasil Analisis Data Respon Peserta Didik terhadap Handout, LKPD dan Proses Pembelajaran pada Uji Coba Terbatas

\begin{tabular}{cccc}
\hline Keterangan & Skor handout & Skor LKPD & Skor Proses Pembelajaran \\
\hline Rata-rata & 39.5 & 25.8 & 43 \\
Kriteria & Sangat praktis & Praktis & Sangat praktis \\
\hline
\end{tabular}

Tabel 10. Hasil Analisis Data Respon Peserta Didik terhadap Handout, LKPD dan Proses Pembelajaran pada Uji Coba Lapangan.

\begin{tabular}{cccc}
\hline Keterangan & Skor handout & Skor LKPD & Skor Proses Pembelajaran \\
\hline Rata-rata & 39 & 25.1 & 43.5 \\
Kriteria & Sangat praktis & Praktis & Sangat praktis \\
\hline
\end{tabular}

Tabel 11. Hasil Analisis Data Observasi Keterlaksanaan Pembelajaran pada Setiap Pertemuan Uji Coba Terbatas

\begin{tabular}{cccccc}
\hline Pertemuan ke- & & $\mathbf{1}$ & $\mathbf{2}$ & $\mathbf{3}$ & $\mathbf{4}$ \\
\hline Jumlah skor persentase keterlaksanaan & Uji coba terbatas & $100 \%$ & $91.7 \%$ & $100 \%$ & $100 \%$ \\
\hline
\end{tabular}

Tabel 12. Hasil Analisis Data Observasi Keterlaksanaan Pembelajaran pada Setiap Pertemuan Uji Coba Lapangan

\begin{tabular}{llllll}
\hline \multicolumn{1}{c}{ Pertemuan ke- } & \multicolumn{1}{c}{$\mathbf{1}$} & \multicolumn{1}{c}{$\mathbf{3}$} & \multicolumn{1}{c}{$\mathbf{4}$} \\
\hline Jumlah Skor & \multirow{2}{*}{ Uji coba Lapangan } & 14 & 12 & 11 & 12 \\
Persentase keterlaksanaan & & $100 \%$ & $100 \%$ & $100 \%$ & $100 \%$ \\
\hline
\end{tabular}


Tabel 13. Hasil Analisis Data Pretest dan Postest (THB) Uji Coba Terbatas

\begin{tabular}{ccc}
\hline Jenis tes & Nilai rata-rata & Persentase kelulusan \\
\hline Pretes & 63 & $0 \%$ \\
Postes (THB) & 90.7 & $100 \%$ \\
\hline
\end{tabular}

Tabel 14. Hasil Analisis Data Pretest dan Postest (THB) Uji Coba Lapangan Kelas Kontrol

\begin{tabular}{ccc}
\hline Jenis tes & Nilai rata-rata & Persentase kelulusan \\
\hline Pretes & 66.8 & $16.7 \%$ \\
Postes $(\mathrm{THB})$ & 79.4 & $66.7 \%$ \\
\hline
\end{tabular}

Tabel 15. Hasil Analisis Data Pretest dan Postest (THB) Uji Coba Lapangan Kelas Eksperimen.

\begin{tabular}{ccc}
\hline Jenis tes & Nilai rata-rata & Persentase kelulusan \\
\hline Pretes & 65 & $0 \%$ \\
Postes $(\mathrm{THB})$ & 89.33 & $100 \%$ \\
\hline
\end{tabular}

Tabel 16. Uji t Keterampilan Proses Sains

\begin{tabular}{|c|c|c|c|c|}
\hline \multicolumn{5}{|c|}{ Independent Samples Test } \\
\hline \multirow[t]{2}{*}{ Data yang diolah } & \multirow[t]{2}{*}{ Data yang dianalisis } & \multicolumn{3}{|c|}{ t-test for Equality of Means } \\
\hline & & $\mathrm{t}$ & Df & Sig. (2-tailed) \\
\hline \multirow{2}{*}{ Postest KPS } & Equal variances assumed & $-4,896$ & 52 & 0,000 \\
\hline & Equal variances not assumed & $-4,977$ & 51,658 & 0,000 \\
\hline
\end{tabular}

Berdasarkan hasil analisis pada Tabel 13 diketahui bahwa pada hasil pretest yaitu tes yang dilakukan sebelum pembelajaran dengan menggunakan produk yang dikembangkan tidak ada seorang peserta didik yang mencapai nilai KKM. Pada hasil posttest (THB) jumlah peserta didik yang telah mencapai nilai KKM bahkan melebihi $70 \%$ yaitu dengan persentase $100 \%$ dengan rata-rata nilai 90.7. Berdasarkan hasil analisis tersebut, perangkat pembelajaran yang dibuat dikatakan efektif untuk penumbuhkembangan KPS pada kelas uji coba terbatas berdasarkan nilai ketuntasan THB.

Berdasarkan hasil analisis pada Tabel 14 dan 15 diketahui bahwa pada hasil pretest yaitu tes yang dilakukan sebelum pembelajaran dengan menggunakan produk yang dikembangkan dilaksanakan baik pada kelas kontrol maupun kelas eksperimen sebagian besar peserta didik belum mencapai nilai KKM. Pada hasil posttest (THB) pada kelas kontrol persentase ketuntasan belajar peserta didik sebesar $66.7 \%$ dengan nilai rata-rata 79.4 sedangkan untuk kelas eksperimen jumlah peserta didik yang telah mencapai nilai KKM bahkan melebihi $80 \%$ yaitu dengan persentase $100 \%$ denga rata-rata nilai 89.33. Berdasarkan hasil analisis tersebut, perangkat pembelajaran biologi berbasis model SLH yang telah digunakan pada kelas eksperimen dikatakan efektif dalam menumbuhkembangkan KPS dan pemahaman konsep.

Tes hasil belajar dilakukan pada akhir pembelajaran untuk mengetahui ketercapaian kompetensi yang telah dipelajari. Keefektifan perangkat pembelajaran terhadap hasil yang dicapai peserta didik diketahui dengan melakukan eksperimen yaitu dengan melihat perbedaan hasil pencapaian nilai hasil belajar terhadap dua kelas yaitu satu kelas eksperimen yang menggunakan perangkat pembelajaran biologi berbasis model SLH setting outdoor activities dan satu kelas kontrol tanpa menggunakan perangkat pembelajaran yang telah dikembangkan tersebut.

Hasil di atas didukung oleh Aktamis \& Ergin dalam (Ergül, Sevgül ÇALI, \& Özdlek, 2011, p. 62) yang menyatakan bahwa mengajarkan keterampilan proses ilmiah kepada peserta didik salah satunya dapat meningkatkan prestasi dalam belajar. Pada penelitian ini, juga dilakukan uji statistika untuk mengetahui keefektifan perangkat pembelajaran biologi yang dikembangkan yaitu dengan melakukan uji t. Hasil dari uji t terdapat pada Tabel 16.

Berdasarkan Tabel 16, bahwa nilai KPS peserta didik memiliki nilai $t$ yang berbeda antara equal variances assumed yaitu $-4,896$ dan equal variances not assumed yang besarnya 4,977. Taraf signifikansi pada equal variances 
assumed 0,000. Karena nilai $p<0,05$ maka $H_{0}$ ditolak atau $H_{a}$ diterima. $H_{a}$ diterima berarti ada perbedaan yang signifikan terhadap hasil penumbuhkembangan KPS antara peserta didik yang mengikuti pembelajaran dengan menggunakan perangkat pembelajaran biologi berbasis model SLH setting outdoor activities dengan perangkat pembelajaran yang biasa digunakan di SMAN 6 Yogyakarta.

Jadi dapat disimpulkan bahwa terdapat perbedaan yang signifikan terhadap hasil penumbuhkembangan KPS antara peserta didik yang mengikuti pembelajaran dengan menggunakan perangkat pembelajaran biologi berbasis model SLH setting outdoor activities dengan perangkat pembelajaran yang biasa digunakan di SMAN 6 Yogyakarta. Hal ini relevan dengan penelitian Yager dan Akcay (2010, p.16) yang menunjukkan bahwa penggunaan dan pemahaman siswa tentang keterampilan sains dan konsep penyelidikan meningkat secara signifikan lebih daripada yang mereka lakukan pada kelas yang tidak diberi perlakuan dalam hal keterampilan proses.

Penilaian terhadap keterampilan proses dengan menggunakan tes tertulis berupa THB dengan menggunakan soal pilihan ganda seperti data yang dianalisis tersebut dengan menggunakan uji statistik juga dilakukan oleh (İncelenmesi et al., 2009, p. 1)untuk mengetahui keterampilan proses sains peserta didik. Ketercapaian KPS selain dengan ketuntasan dari THB dengan pengujian statistik juga menggunakan lembar observasi. Data hasil observasi KPS peserta didik terdapat pada Tabel 17.

Berdasarkan hasil analisis terhadap data ketercapaian penumbuhkembangan KPS melalui lembar observasi pada Tabel 17 diketahui perolehan skor rata-rata KPS untuk kelas uji coba terbatas adalah $36.3>32.5$ sehingga ketercapaian penumbuhkembangan KPS masuk pada krtiteria sangat baik, untuk observasi pada uji coba lapangan di kelas kontrol adalah $29.8>25$ memenuhi kriteria baik dan untuk kelas eksperimen adalah $36.5>32.5$ memenuhi kriteria sangat baik.

Berdasarkan hasil analisis tersebut diketahui bahwa kelas eksperimen yang menggunakan perangkat pembelajaran berbasis model SLH pada proses pembelajaran lebih unggul untuk menumbuhkembangkan KPS dibandingkan kelas kontrol yang tidak menggunakan perangkat pembelajaran yang dikembangkan tersebut. Hal ini terjadi karena model SLH yang digunakan pada penelitian menggunakan sintak pembelajaran berbasis inkuiri sehingga lebih efektif dalam menumbuhkembangkan KPS peserta didik dalam proses pembelajaran dibandingkan pada kelas kontrol yang secara konvensional yaitu hanya melalui diskusi dan tanya jawab dalam proses pembelajaran.

Keefektifan perangkat pembelajaran juga dilihat dari hasil ketercapaian penumbuhkembangan karakter peduli lingkungan. Upaya pengembangan karaker didesain melalui perangkat pembelajaran yang dikembangkan. Hasil capaian karakter peserta didik dapat diketahui dari hasil analisis berdasarkan data dari angket karakter. Angket karakter yang akan digunakan di lapangan terlebih dahulu divalidasi oleh ahli secara teori. Setelah di uji ahli, angket dinyatakan valid dan layak digunakan. Angket yang telah dinyatakan valid dan layak, digunakan pada uji coba untuk memperoleh data keefektifan produk dalam penumbuhkembangan KPL. Angket diberikan sebagai pretest yaitu sebelum pembelajaran dilakukan dan sebagai posttest yaitu setelah semua pembelajaran selesai. Skor ketercapaian pada pretest dan posttest kemudian dianalisis untuk melihat ada tidaknya peningkatan. Skor capaian karakter peserta didik yang diperoleh dari hasil pengisian angket KPL terdapat pada Tabel 18, 19 dan 20.

Tabel 17. Data Hasil Observasi KPS Peserta Didik

\begin{tabular}{clcc}
\hline No & \multicolumn{1}{c}{ Kelas Uji coba } & Skor rata-rata KPS & Kriteria \\
\hline 1 & Uji coba Kecil & 36.3 & Sangat baik \\
2 & Uji coba Lapangan kelas kontrol & 29.8 & Baik \\
3 & Uji coba lapangan kelas eksperimen & 36.5 & Sangat baik \\
\hline
\end{tabular}

Tabel 18. Hasil Pencapaian Karakter Peduli Lingkunga Uji Coba Terbatas

\begin{tabular}{ccccc}
\hline \multirow{2}{*}{ No } & \multirow{2}{*}{ Peserta Didik } & \multicolumn{2}{c}{ Jumlah } & \multirow{2}{*}{ Ket } \\
\cline { 2 - 4 } & & pretest & posttest & \\
\hline 1 & HMD & 68 & 92 & Terjadi peningkatan \\
2 & AAA & 80 & 91 & Terjadi peningkatan \\
3 & AZAF & 92 & 97 & Terjadi peningkatan \\
4 & TDN & 90 & 96 & Terjadi peningkatan \\
\hline
\end{tabular}


Jurnal Inovasi Pendidikan IPA, 2 (1), 2016 - 131

Riya Irianti, Heru Nurcahyo

\begin{tabular}{llccc}
\hline 5 & GEC & 79 & 96 & Terjadi peningkatan \\
6 & AMA & 93 & 105 & Terjadi peningkatan \\
\hline
\end{tabular}

Tabel 19. Hasil Pencapaian Karakter Peduli Lingkunga Uji Coba Lapangan Kelas Kontrol

\begin{tabular}{lll}
\hline \multicolumn{1}{c}{ Pengambilan data } & Skor Rata-rata & Keterangan \\
\hline Pra Pembelajaran & 85.3 & Terjadi peningkatan sebesar 2.9 \\
Pasca Pembelajaran & 88.2 & \\
\hline
\end{tabular}

Tabel 20. Hasil Pencapaian Karakter Peduli Lingkunga Uji Coba Lapangan Kelas Eksperimen

\begin{tabular}{lcl}
\hline \multicolumn{1}{c}{ Pengambilan data } & Skor Rata-rata & Keterangan \\
\hline Pra Pembelajaran & 88.2 & Terjadi peningkatan sebesar 8.3 \\
Pasca Pembelajaran & 96.5 & \\
\hline
\end{tabular}

Tabel 21. Uji t Karakter Peduli Lingkungan

\begin{tabular}{lllllr}
\hline \multicolumn{4}{c}{ Independent Samples Test } \\
\hline \multicolumn{1}{c}{ Data yang diolah } & \multicolumn{2}{c}{ Data yang di interpretasi } & \multicolumn{3}{c}{ t-test for Equality of Means } \\
\hline \multirow{3}{*}{ Postest KPL } & & t & Df & \multicolumn{2}{c}{ Sig. (2-tailed) } \\
& Equal variances assumed & $-5,199$ & & 52 & 0,000 \\
& Equal variances not assumed & $-5,133$ & 46.661 & 0,000 \\
\hline
\end{tabular}

Berdasarkan data angket karakter pada Tabel 18 yaitu angket yang diberikan pada subjek uji coba terbatas terlihat terjadi peningkatan skor. Hal ini dapat dilihat dari lebih tingginya skor pada posttest dibanding skor pada pretest. Hal ini dapat mengindikasikan bahwa proses belajar dengan menggunakan perangkat pembelajaran yang dikembangkan efektif menumbuhkembangkan KPL pada peserta didik uji coba terbatas.

Berdasarkan data pada subyek uji coba lapangan pada Tabel 19 dan 20 menunjukkan bahwa terjadi peningkatan yang lebih baik dari kelas kontrol dan eksperimen. Analisis peningkatan ini bukan hanya ditinjau hal tersebut saja tetapi juga dilihat dari nilai peningkatan KPL. Pada kelas eksperimen nilai peningkatan KPL lebih besar yaitu dari rata-rata 88.2 menjadi 96.5 dengan peningkatan sebesar 8.3 sedangkan pada kelas kontrol dari skor 85.3 menjadi 88.2 dengan peningkatan sebesar 2.9. Selain dengan melihat nilai peningkatan angket KPL dari pra dan pasca pembelajaran analisis ketercapaian penumbuhkembangan KPL pada proses pembelajaran dengan menggunakan perangkat pembelajaran berbasis model SLH juga dilakukan dengan uji statistik yaitu dengan melakukan uji t. Hasil dari uji t terdapat pada Tabel 21.

Berdasarkan Tabel 21, bahwa nilai KPL peserta didik memiliki nilai $t$ yang berbeda antara equal variances assumed yaitu - 5,199 dan equal variances not assumed yang besarnya $-5,133$. Taraf signifikansi pada equal variances assumed 0,000 . Karena nilai $p<0,05$ maka $H_{0}$ ditolak atau $H_{a}$ diterima. $H_{a}$ diterima berarti ada perbedaan yang signifikan terhadap hasil penumbuhkembangan KPL antara peserta didik yang mengikuti pembelajaran dengan menggunakan perangkat pembelajaran biologi berbasis model SLH setting outdoor activities dengan perangkat pembelajaran yang biasa digunakan di SMAN 6 Yogyakarta.

Berdasarkan analisis data statistik tersebut maka dapat dinyatakan terdapat perbedaan yang signifikan terhadap hasil penumbuhkembangan KPL antara peserta didik yang mengikuti pembelajaran dengan menggunakan perangkat pembelajaran biologi berbasis model SLH setting outdoor activities dengan perangkat pembelajaran yang biasa digunakan di SMAN 6 Yogyakarta. Model SLH yang digunakan pada penelitian ini dengan setting outdoor activities sebagai setting pembelajaran, memberikan pengalaman belajar riil pada peserta didik sehingga potensi penumbuhkembangan KPL menjadi lebih efektif dibandingkan dengan kelas kontrol yang secara konvensional dalam proses pembelajaran. Dengan demikian dapat disimpulkan bahwa perangkat pembelajaran berbasis model SLH efektif menumbuhkembangkan KPL ditinjau dari skor angket KPL yang diperoleh peserta didik.

Beberapa keterbatasan yang terdapat pada penelitian ini meliputi model pembelajaran yang digunakan pada pengembangan perangkat pembelajaran biologi SMA yang menumbuhkembangkan KPS dan KPL masih terbatas pada model Susan Loucks Horsley. Uji kelayakan perangkat pembelajaran berupa angket KPL terbatas pada validasi ahli saja. Instrumen untuk mengukur KPL terbatas pada lembar angket 


\section{Jurnal Inovasi Pendidikan IPA, 2 (1), 2016 - 132}

Riya Irianti, Heru Nurcahyo

saja. Uji coba produk hanya dilakukan pada satu sekolah saja yaitu SMAN 6 Yogyakarta. Lama kegiatan pembelajaran tentang cara daur ulang sampah dengan pengomposan hanya satu minggu saja dikarenakan keterbatasan waktu. Sumber belajar untuk setting outdooar activities hanya pada satu pasar tradisional saja.

\section{SIMPULAN}

Berdasarkan hasil penelitian dan pembahasan diperoleh simpulan bahwa produk perangkat pembelajaran biologi berbasis model Susan Loucks-Horsley setting outdoor activities yang dikembangkan terdiri atas silabus, RPP, handout, Lembar Kegiatan Peserta Didik (LKPD), dan lembar instrumen penilaian termasuk dalam kriteria sangat valid berdasarkan penilaian kelayakan isi, tampilan dan manfaat yang telah di validasi oleh ahli materi, ahli pembelajaran, praktisi dan teman sejawat. Produk perangkat pembelajaran biologi berbasis model Susan Loucks-Horsley setting outdoor activities yang terdiri atas handout, Lembar Kegiatan Peserta Didik (LKPD), dan proses pembelajaran yang dikembangkan termasuk dalam kriteria sangat praktis untuk handout dan proses pembelajaran serta praktis untuk LKPD. Penilaian berdasarkan aspek isi, manfaat serta kemudahan dalam menggunakan oleh peserta didik pada kelas uji coba terbatas dan kelas eksperimen pada uji coba lapangan. Penilaian juga berdasarkan pada keterlaksanaan pembelajaran yang menunjukkan bahwa persentase keterlaksanaan pembelajaran berada pada kisaran $91,7 \%$ sampai $100 \%$ pada setiap pertemuan.

Produk perangkat pembelajaran biologi untuk kelas X yang terdiri atas silabus, RPP, handout, Lembar Kegiatan Peserta Didik (LKPD), dan lembar instrumen penilaian termasuk dalam kriteria efektif dalam menumbuhkembangkan KPS peserta didik. Penilaian keefektifan berdasarkan ketuntasan hasil belajar dalam menyelesaikan THB dan skor ketercapaian KPS. Produk perangkat pembelajaran biologi untuk kelas X yang terdiri atas silabus, RPP, handout, Lembar Kegiatan Peserta Didik (LKPD), dan lembar instrumen penilaian termasuk dalam kriteria efektif dalam menumbuhkembangkan KPL peserta didik. Penilaian keefektifan berdasarkan skor ketercapaian karakter pada angket KPL.

\section{DAFTAR PUSTAKA}

Akcay, H., Yager, R. E., Iskandar, S. M., \& Turgut, H. (2010). Change in Student beliefs about attitudes toward science ingrades 6-9. Asia -pasific forum on science learning and teaching, Volume 11, Issue 1, Article 1, p.1 (Jun., 2010).

Bundu, P. (2006). Penilaian keterampilan proses dan sikap ilmiah dalam pembelajaran sains SD. Jakarta: Departemen Pendidikan Nasional.

Depdiknas.(2008). Pendekatan, jenis, dan metode penelitian pendidikan. Jakarta: Direktorat Tenaga Kependidikan.

Direktorat Pembinaan SMA. 2010. Juknis penyusunan perangkat penilaian afektif di SMA. Direktorat Pembinaan SMA

Ergül, R., Sevgül ÇALI, Y., \& Özdlek, Z. (2011). The effects of inquiry-based science teaching on elementary school students' science process skills and science attitudes. Bulgarian Journal of Science and Education Policy, 5(1).

İncelenmesi, E., Yalçin, S. A., Turgut, Ü., Altun, S., 82, Y., Kelimeler, A., ... Tutum, F. K. (2009). The effect of project based learning on science undergraduates' learning of electricity, attitude towards physics and scientific process skills. International Online Journal of Educational Sciences, 1(1), 81-105. Retrieved from www.iojes.net

Kemendikbud. (2013a). Permendiknas No.64 tahun 2013 tentang isi pendidikan dasar dan menengah. Jakarta: Kementerian Pendidikan dan Kebudayaan Republik Indonesia.

McCormack, A.J. (1992). Trend and issues in science curriculum. San Diego State University, San Diego, California.

Nieveen, N. (1999). Prototyping to reach product quality. London: Kluwer Academic Publisher.

Rezba, R.J., Sprague, C., McDonnough, J.T.1. (2006). Learning and assessing science process skills. Dubuque, Iowa: Kendall/Hunt Publishing Company.

Semiawan, C., Tangyong, A.F., Belen, S., Matahelemual, Y., \& Suseloardjo, W. (1992). Pendekatan keterampilan proses. Jakarta: Gramedia.

Supahar, S. (2010). Menanamkan keterampilan proses sains IPA pada peserta didik 


\section{Jurnal Inovasi Pendidikan IPA, 2 (1), 2016 - 133}

Riya Irianti, Heru Nurcahyo

dengan strategi pembelajaran outdoor activities dalam kegiatan Lesson Study Berbasis Sekolah (LSBS). Prosiding Seminar Nasional Penelitian, Pendidikan dan penerapan MIPA, Fakultas MIPA, di Universitas Negeri Yogyakarta.
Trianto. (2009). Mendesain perangkat pembelajaran inovatif-progresif, konsep, landasan, dan implementasinya pada KTSP. Jakarta: Kencana Prenada Media Group.. 